International Research Journal of Engineering, IT \& Scientific Research
Available online at https://sloap.org/journals/index.php/irjeis/
Vol. 5 No. 4, July 2019, pages: 46 54
ISSN: 2454-2261
https://doi.org/10.21744/irjeis.v5n4.693

\title{
Piper Caninum Blume Leaf Extract and Compost to Suppress Blast Disease and Increase the Production of Bali Red Rice (Oryza Sativa) in Green House
}

Article history:

Received: 27 March 2019

Accepted: 31 May 2019

Published: 31 July 2019

Keywords:

blast disease;

compost;

liquid organic;

piper caninum;

rice crop;

\begin{abstract}
The parameters developed in organic farming are the use of vegetable pesticides and compost and liquid organic fertilizer. Some research has been done but it needs deeper research to get the right product. The purpose of this study was to determine the inhibitory activity of Piper caninum extract against the fungus Pyricuaria oryzae causing blast disease in rice, and to find out how much the impact of compost on increased crop yield after being combined with the extract. This is a field research located in the village of Senganan, Penebel Tabanan Bali. With the following treatment Fo = control $(100 \%$ soil $) . \mathrm{F} 1=($ soil $90 \%+$ compost $10 \%+$ extract $0.5 \%) . \mathrm{F} 2=($ soil $80 \%$ + compost $20 \%+$ extract $1 \%) \mathrm{F} 3=($ soil $70 \%+30 \%+$ extract $1.5 \%) . \mathrm{F} 4=$ (soil $60 \%+$ compost $40 \%+2 \%$ extract), do repeat 4 times. The results showed that $P$. caninum extract effectively inhibited blast disease and could reduce the intensity of blast disease. The combination with compost can significantly increase yields $(67.62 \%)$, reduce empty grains, and increase rice size.
\end{abstract}

2454-2261 ${ }^{\circledR}$ Copyright 2019. The Author. This is an open-access article under the CC BY-SA license (https://creativecommons.org/licenses/by-sa/4.0/) All rights reserved.

\section{Author correspondence:}

Ni Luh Suriani,

Department of Biology Matematics and Natural Science Faculty

Udayana University, Kampus Bukit Jimbaran Badung, Bali, Indonesia.

Email address: niluhsurianisuriani@yahoo.com

\section{Introduction}

Synthetic pesticides have been used for a long time and experienced an explosion in the eighties to the nineties, which was used to increase crop production. But after knowing the impact on the environment, people began to switch to organic farming (Razu \& Hossain, 2015). Many things have been developed to support organic farming such as the use of liquid and solid organic fertilizers, the use of biological agents, the use of plant extracts to suppress disease in plants and to increase agricultural output. The use of biological agents such as Trichoderma to control blast disease and other diseases in rice has been carried out (Akhilesh et al., 2017; Yadav et al., 2018; Eiham et al., 2012; Yutida et al., 2014).

${ }^{a}$ Udayana University, Denpasar, Indonesia 
The use of organic fertilizers both liquid and solid has been widely done but not optimal (Suriani et al., 2015), as well as the use of biological agents, the use of extracts (Suprihatno et al., 2012), as biopesticides is not optimal. A lot of research has been done in the organic field, but most of them are individual. Such as the use of compost without being accompanied by the use of biological agents or extracts. So the results obtained are not optimal. The success of agriculture is due to the integration factor between the use of fertilizers, pesticides, and climate factors often referred to as integrated plant disease prevention (Rahmawati \& Carolina, 2009; Suriani, 2018; Singh, 2017). If one factor is not optimal, it will affect plant production. Research on the use of extracts on inhibition and plant production has been done but not yet optimal, such as too much extract, the plant will be disturbed growth. Likewise, the efficiency factor is lacking. Suriani et al., (2015), the study showed that $P$. caninum extract can inhibit blast disease and can increase yields, at optimal concentrations of $3 \%$. But the extract is used too much, it is less effective.

Research on the use of compost has been done but is still less efficient, too much compost or organic fertilizer added to the media. In this research there will be an increase in the efficiency of the use of extracts as biopesticides and the efficient use of compost, to suppress blast disease and increase crop yields in rice plants especially red Balinese rice. Because it will be combined between extracts with compost to suppress blast disease and increase crop yields. Using Bali red rice because this rice is a symbol of Bali rice, the only one is in Bali and more specifically only in the area of Tabanan Bali (Fumitaka et al., 2015). Preserving local wisdom to support sustainable tourism in Bali.

\section{Materials and Methods}

\section{Preparation of P. caninum Blume exract}

Forests chili leaves (P. caninum Blume) were collected from plants grown in the Village of Senganan, Penebel District, Tabanan Regency Bali. The materials were then macerated in methanol at a ratio of 1:10 (weight/volume) for 48 hours in the dark, at room temperature. The filtrate was obtained by filtering, using 4 layers of gauze followed by filtration using Whatman filter paper No. 1. The maceration process was done 3 times with methanol. The filtrate obtained was combined and then evaporated using a rotary evaporator (Iwaki, Tokyo) at $40^{\circ} \mathrm{C}$ to separate the solvent (methanol) and the extract. The crude extract obtained was ready for the next test.

\section{Antifungy screening}

The extract formula was first diluted with sterile water to become an extract with a concentration of $0.5 \%$; $1 \%$, $1.5 \% ; 2 \%$. Application of extract formula is done by spraying using a sprayer four times, the first application 24 hours after education, the second, third and fourth applications are carried out at 7 days interval. The dose of the extract formula for each spray is $20 \mathrm{ml}$ per clump. Treatment with a concentration of $0 \%$ was carried out by spraying $20 \mathrm{ml}$ of sterile water/rice clump.

\section{Preparation of compost}

Making trichocompos organic fertilizer with a capacity of $1000 \mathrm{~kg}$ is: $800 \mathrm{~kg}$ cow manure mixed with $194 \mathrm{~kg}$ agricultural waste, sprinkled with $3 \mathrm{~kg}$ biostater, doused with $3 \mathrm{~L}$ liquid biostater then stirred evenly, then covered with tarpaulin left for 20 days then opened and stirred again, then closed again. After 40 days the compost is ready to be used.

\section{Preparation of fertilizer formulation}

In this study the extracts were combined with organic fertilizer which was made by biotechnology stater starmik $o k$. Fo $=$ control $($ soil $100 \%) . \mathrm{F} 1=($ soil $90 \%+$ compost $10 \%+$ extract $0,5 \%) . \mathrm{F} 2=($ soil $80 \%+$ compost $20 \%+$ extract $1 \%) \mathrm{F} 3=($ soil $70 \%+30 \%+$ extract $1.5 \%) . \mathrm{F} 4=($ soil $60 \%+$ compost $40 \%+2 \%$ extract $)$, do repeat 4 times.

\section{Rice cultivation}

The cultivation of rice was conducted at Village of Senganan, Penebel, Tabanan Bali from January 2018 until July 2018 Latitude 600 DPL. This research was conducted in a greenhouse with a size of $10 \mathrm{~m} \mathrm{x} 10 \mathrm{~m}$. randomized block design (RBD) consisting of 5 treatments: Each experimental unit consisted of 10 clumps rice plants. Implementation of the experiment includes: seeding, planting media preparation, fertilizing, plant maintenance, inoculation of pathogenic fungi ( $P$. oryzae), vegetable fungicide application.

Suriani, N. L. (2019). Piper caninum blume leaf extract and compost to suppress blast disease and increase the production of bali red rice (oryza sativa) in green house. International Research Journal of Engineering, IT \& Scientific Research, 5(4), 46-54. https://doi.org/10.21744/irjeis.v5n4.693 
Seeding

The rice seeds of the Ciherang variety were previously soaked in clean water for 24 hours, then drained, and placed in a container containing wet tissue for 24 hours so that the seeds germinate. Then the germinating seeds are sown on a tray that has been filled with planting media. The planting medium for treatment is topsoil paddy soil (20 $\mathrm{cm}$ from the surface). The seeds that have been sown are then watered and the seedling media is not dried. After 15 days old, it is removed to be planted in a pot.

Preparation of planting media

Media of paddy soil ( $20 \mathrm{~cm}$ from the surface) is mashed and then put into a pot, then added water, stirred to form mud. Added compost according to Formula to the planting media then left for 2 weeks. This planting media is ready to use.

\section{Planting}

The seeds used are healthy seedlings of uniform $\pm 15 \mathrm{~cm}$ high, 15 days after seedling, free from pests and diseases. Seed extraction and planting are carried out in the morning. Each pot is planted by 2 rice seeds. Planting is done perpendicular to $\pm 3 \mathrm{~cm}$ depth. Maintenance of rice plants carried out includes planting, watering, weeding, and fertilizing. Embedding is done on plants that do not grow or abnormal growth with plants that have been prepared in advance in the tray so that the growth is uniform. Watering is done since planting and is done every day (morning or evening). Weeding is done to keep plants from being disturbed by weeds to prevent nutrient competition between weeds and rice plants.

\section{Inoculation of P. Oryzae}

P. Oryzae inoculation on rice plants was carried out after rice plants were 30 days after planting (HST), carried out by spraying $20 \mathrm{ml}$ of a suspension of mushroom spores per clump using hands prayer, then covered with plastic for 12 hours to maintain moisture. Spores $P$. oryzae were obtained by harvesting pure culture of $P$. oryzae on sloping media with $10 \mathrm{ml}$ of sterile water, then harvesting them with ose needles, being examined for 1 minute and filtered with Whatman No.2 filter paper. 2 to separate the mushroom spores from the hyfa. The mushroom spores obtained were diluted with sterile water until the volume became $20 \mathrm{ml}$. The density of mushroom spores used is $25 \times 104$ spores / $\mathrm{m}$.

\section{Application extract}

The extract formula was first diluted with sterile water to become an extract with a concentration of $0.5 \% 1 \%$; $1.5 \% ; 2 \%$. Application of extract formula is done by spraying using a sprayer four times, the first application 24 hours after education, the second, third and fourth applications are carried out at 7 days intervals. The dose of the extract formula for each spray is $20 \mathrm{ml}$ per clump. Treatment with a concentration of $0 \%$ was carried out by spraying $20 \mathrm{ml}$ of sterile water/rice clump.

\section{Parameter}

The observed parameters covered intensity of blast disease, Measurement of the intensity of the blast disease was done by the following formula Sinaga (2006), I P $=\frac{\sum_{i=0}^{i}(n i . v i)}{N V} \times 100 \%$. Where IP = Intensity of disease $(\%)$, ni $=$ Number of leaves with a score $\mathrm{i}, \mathrm{vi}=$ Value of each category of disease scores, $\mathrm{N}=$ number of leaves were observed, $\mathrm{V}=$ highest score. Component of yield (Number of productive tillers; the number of grain/panicle; full-grain weight/clump (g); \% empty grain/clump; potential yield (ton/ha); yield increase compared with control).

\section{Data Analysis}

The data obtained were analyzed quantitatively using analysis of variance one way ANOVA $(\mathrm{p}<0.05)$ and expressed as mean values. If the treatment causes a difference to the observed variables, then Duncan's Multiple Range Test (DMRT) at the 5\% level was used. 


\section{Results and Discussions}

\subsection{Intensity of Blast Disease}

P. caninum leaf extract combined with compost fertilizer significantly affected the intensity of blast disease at 12 MST ( $\mathrm{P}<0.05)$. With the lowest intensity, there was an extract concentration of $1.5 \%$ with $30 \%$ compost. P. caninum extract contains bioactive substances such as alkaloids, flaphonoids, polyphenols, steroids that are as antifungal agents, besides that they contain antimicrobials. Bioactive substances lyse fungal cells and damage the fungal cell walls, so that cell fluid will come out and the cells experience death (Salleh et al., 2011; 2015; Suriani, 2016; Suryani \& Arya, 2017; Sukada et al., 2019; Chouhan et al., 2017; Randrianariveloa, 2009). Sena et al., (2013), state that bioactive substances in Epicoccum sp extract can reduce enzymatic activity in $P$. oryzae fungi that cause rice blast disease.

Table 1

The intensity of blast disease and inhibiting activity after 12 MST

\begin{tabular}{llcl}
\hline No & Treatment & $\begin{array}{l}\text { Intensity of blast } \\
\text { disease }(\%)\end{array}$ & Inhibiting activities $(\%)$ \\
\hline 1 & F0 & $80.15 \mathrm{a}^{*}$ & - \\
2 & F1 & $51.23 \mathrm{~b}$ & 36.08 \\
3 & F2 & $31.15 \mathrm{c}$ & 61.14 \\
4 & F3 & $10.16 \mathrm{~d}$ & 86.25 \\
5 & F4 & $16.33 \mathrm{~d}$ & 79.63 \\
\hline
\end{tabular}

* Figures followed by the same letter do not show significant difference based on Duncan multiple range test at the level of $5 \%$. ( F0= control; F1=extracts $0.5 \%+$ compost $10 \% ; \mathrm{F} 2=$ extract $1 \%+$ compost $20 \% ; \mathrm{F} 3=$ extracts $1,5 \%+$ compost $30 \%$; F4= extract $2 \%+$ compost $40 \%)$.

Table 1 shows that the higher the concentration of extract and compost, the intensity of blast disease decreases, it applies until the treatment of F3, while the intensity of the F4 tune increases but it is not significantly different from F3. The development of blast disease is shown in Figure 1, were at week 12 MST the intensity of the disease has increased due to the influence of the extract has begun to decrease because many factors including degraded and evaporated into the air. Besides the effect of extracts, the effect of compost is also very large in controlling blast disease. Because compost is a source of plant nutrition, plants become more resistant to disease. The use of compost on agricultural land can increase the resilience of plants against disease. The use of compost can also increase the production of anthurium cut flowers and ornamental plants, the higher the compost concentration, the higher the production of semi flowers and ornamental plants (Suriani et al., 2015; Parwanayoni \& Suriani, 2015).

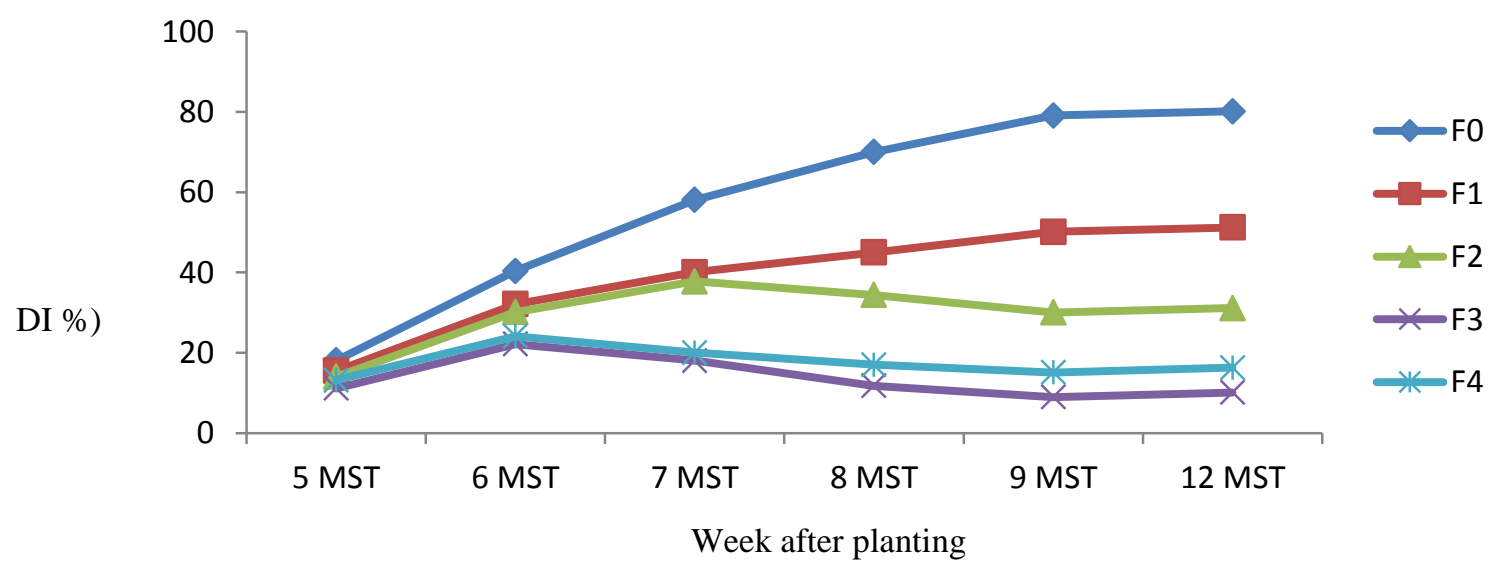

Figure 1. Intensity development of blast disease during spraying with extracts

Suriani, N. L. (2019). Piper caninum blume leaf extract and compost to suppress blast disease and increase the production of bali red rice (oryza sativa) in green house. International Research Journal of Engineering, IT \& Scientific Research, 5(4), 46-54. https://doi.org/10.21744/irjeis.v5n4.693 


\subsection{Results Component}

Formulation of leaf extract of forest chili in combination with compost significantly affected $(\mathrm{P}<0.05)$ on rice yield components (Table2 and Figure 2). The number of productive tillers in F3 treatment (extract $1.5 \%$ combined with compost $30 \%$ ) showed the highest number of tillers and decreased in F4 treatment (extract $2 \%$ combined with compost 40\%). Likewise, for the data on the number of grains/panicles, the weight of rice grains/clumps, the potential yield of tons/ha and the increase in yield compared to controls. For the percentage of empty grains / the highest clump in the control and the lowest in the F3 treatment, and increased again in the F4 treatment. This is because in the treatment of F4 extract begins to be toxic to rice plants because of excessive concentration. The intensity of the disease increased at $2 \%$ extract concentration and $40 \%$ compost, while the yield component decreased. Suriani (2015), extracts of forest chili leaves were toxic to ciphering rice plants at a concentration of $3.5 \%$.

Compost fertilizer with a biostater can increase the weight of dry grain per ha by 3.45 tons (Suriani et al., 2015). Sennang et al., (2012), that organic fertilizers and biological fertilizers can increase the yield of dry grain with an average grain containing 167.07 / panicle. According to Yuliani \& Maryana (2014), controlling blast disease is carried out in an integrated manner, one of which is balanced fertilization. Suwandi et al., (2012), that integrated control, one of which is biological fertilizers can suppress disease in tidal rice plants in the Banyuasin area. Adding too much organic fertilizer causes a decrease in rice yields (Padmanabha et al., 2014).

Table 2

Effect of leaf extract treatment on yield component of rice plants

\begin{tabular}{lllll}
\hline Treatment & $\begin{array}{l}\text { Tillers } \\
\text { Productive }\end{array}$ & $\begin{array}{l}\text { Number of } \\
\text { grain/panicule }\end{array}$ & $\begin{array}{l}\text { Full grain } \\
\text { weight/clump (gram) }\end{array}$ & $\begin{array}{l}\text { Percentage of empty } \\
\text { grain/clump }(\%)\end{array}$ \\
\hline Fo & $8,89 a^{*}$ & $218,10 a^{*}$ & $40,50 a^{*}$ & $10,74 a^{*}$ \\
F1 & $9,70 \mathrm{~b}$ & $236,21 \mathrm{~b}$ & $50.20 \mathrm{~b}$ & $8,49 \mathrm{~b}$ \\
F2 & $10,90 \mathrm{c}$ & $236.22 \mathrm{c}$ & $59,60 \mathrm{c}$ & $6,52 \mathrm{c}$ \\
F3 & $13,14 \mathrm{~d}$ & $239.81 \mathrm{~d}$ & $78,67 \mathrm{~d}$ & $2,49 \mathrm{e}$ \\
F4 & $10,02 \mathrm{c}$ & $237,88 \mathrm{~b}$ & $62,53 \mathrm{~b}$ & $3,99 \mathrm{~d}$ \\
\hline
\end{tabular}

* Numbers followed by the same letters in the same column show no significant difference based on Duncan Multiple Range Test at 5\% level.

Table 3

Potential yield and yield Increase

\begin{tabular}{ll}
\hline $\begin{array}{l}\text { Potential yield } \\
\text { (ton/ha) }\end{array}$ & $\begin{array}{l}\text { Yield increase compared } \\
\text { with control }\end{array}$ \\
\hline $3.15 \mathrm{a}^{*}$ & - \\
$3,45 \mathrm{a}$ & 9.52 \\
$4.20 \mathrm{~b}$ & 33.33 \\
$5.28 \mathrm{c}$ & 67.62 \\
$5.11 \mathrm{c}$ & 62.22 \\
\hline
\end{tabular}




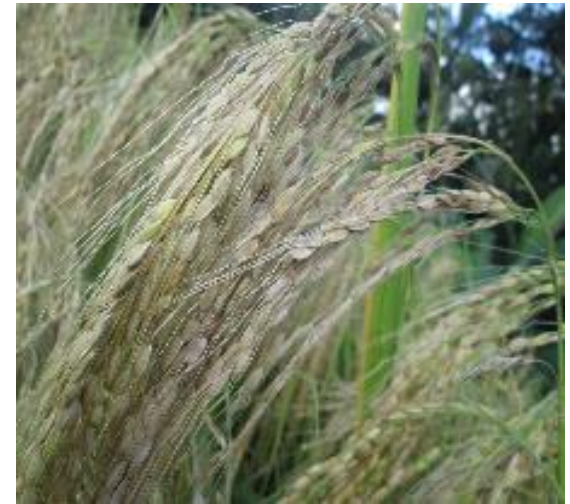

F0

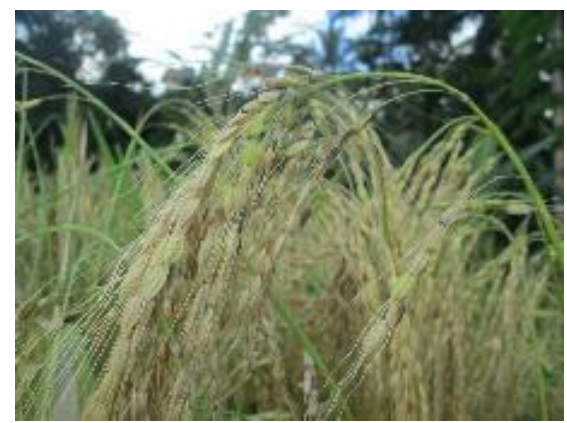

F2

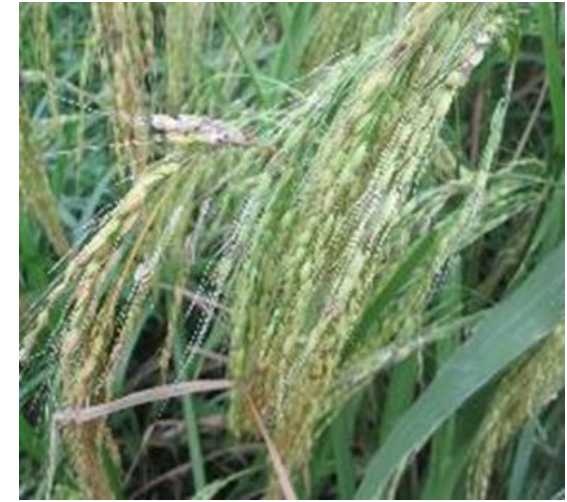

F1

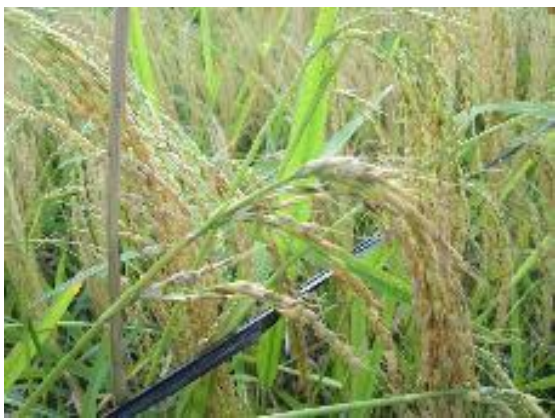

F3

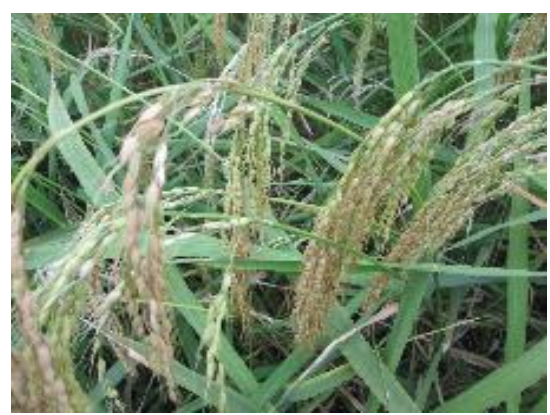

F4

Figure 2. Harvesting time 14 week after transplant

\section{Conclusion}

Leaf extract of forest chili in combination with compost significantly affects the production of Bali red rice. The most appropriate formula to increase production is $1.5 \%$ extract concentration combined with $30 \%$ compost.3. $1.5 \%$ extract concentration combined with $30 \%$ compost can increase rice production by $75.15 \%$ in control.

Conflict of interest statement and funding sources

The authors declared that they have no competing interest.

Suriani, N. L. (2019). Piper caninum blume leaf extract and compost to suppress blast disease and increase the production of bali red rice (oryza sativa) in green house. International Research Journal of Engineering, IT \& Scientific Research, 5(4), 46-54. https://doi.org/10.21744/irjeis.v5n4.693 
Statement of authorship

The authors have a responsibility for the conception and design of the study. The authors have approved the final article.

Acknowledgments

We would like to thank DIKTI has funded this research which has funded this research, and the Lab. Biopesticide Unud which has facilitated the implementation of this research. 


\section{References}

Chouhan, S., Sharma, K., \& Guleria, S. (2017). Antimicrobial activity of some essential oils-present status and future perspectives. Medicines, 4(3), 58.

Fumitaka, S., \& Yasuhiko, H. (2005). MCI. 186 (edaravone). a free radicalscavenger, attenuates hepatic walTn ischemia-reperfusion injury inrats. Transplant International, 18(7), 848-853.

Khalili, E., Sadravi, M., Naeimi, S., \& Khosravi, V. (2012). Biological control of rice brown spot with native isolates of three Trichoderma species. Brazilian Journal of Microbiology, 43(1), 297-305. http://dx.doi.org/10.1590/S1517-83822012000100035

Kulmitra, A. K., Sahu, N., Kumar, V. B., Thejesha, A. G., Ghosh, A., \& Gulnaz, Y. (2017). In vitro evaluation of bio-agents against Pyricularia oryzae (Cav.) causing rice blast disease. Agricultural Science Digest, 37(3).

Padmanabha, I. G., Arthagama, I. D. M., \& Dibia, I. N. (2014). Pengaruh dosis pupuk organik dan anorganik terhadap hasil padi (Oriza sativa L.) dan sifat kimia tanah pada Inceptisol Kerambitan Tabanan. E-Jurnal Agroekoteknologi Tropika, 3(1), 41-50.

Rachmawati, D., \& Karlina, E. (2009). Pemanfaatan Pestisida Nabati untuk Mengendalikan Organisme Pengganggu Tanaman. Balai Pengkajian Teknologi Pertanian Jawa Timur, Departemen Pertanian.

Randriana, B., Irles, M., Albert, B., Casenave, C., Baron, J. F., Nottin, P., \& Paz Galvez, R. (1994). Hématocolpos unilatéral, vagin borgne et agénésie de l'arbre urinaire homolatéral. Revue française de gynécologie et d'obstétrique, 89(7-9), 401-405.

Razu, M. A. U., \& Hossain, I. (2015). Eco-friendly management of rice diseases. International Journal of Applied Sciences and Biotechnology, 3(1), 80-88. https://doi.org/10.3126/ijasbt.v3i1.11977

Salleh, W. M. N. H. W., Ahmad, F., \& Yen, K. H. (2015). Chemical constituents from Piper caninum and antibacterial activity. Journal of Applied Pharmaceutical Science, 5(06), 020-025.

Salleh, W. M. N. H. W., Ahmad, F., Yen, K. H., \& Sirat, H. M. (2011). Chemical compositions, antioxidant and antimicrobial activities of essential oils of Piper caninum Blume. International journal of molecular sciences, 12(11), 7720-7731. https://doi.org/10.3390/ijms12117720

Sena, A., Chaibub, A. A., Côrtes, M. V., Silva, G. B., Silva-Lobo, V. L., Prabhu, A. S., ... \& Araújo, L. G. (2013). Increased enzymatic activity in rice leaf blast suppression by crude extract of Epicoccum sp. Tropical Plant Pathology, 38(5), 387-397. http://dx.doi.org/10.1590/S1982-56762013005000028

Sennang, N. R., Syam'un, E., \& Dachlan, A. (2012). Pertumbuhan dan produksi padi yang diaplikasi pupuk organik dan pupuk hayati. J. Agrivigor, 11(2), 161-170.

Sinaga, E. (2006). CurcumadomesticaVal.

Singh, D. (2017). Leaf phenology of cassia Sieberiana L. in KSUSTA campus of Kebbi state, Nigeria. International Journal of Life Sciences, 1(1), 1-8. https://doi.org/10.21744/ijls.v1i1.8

Sukada, I. K., Suberata, I. W., \& Rasna, N. M. A. (2019). Immersion effect with extracts of papaya leaf, pineapple, ginger on quality of organoleptic and Bali beef nutrition. International Journal of Life Sciences, 3(1), 12-24. https://doi.org/10.29332/ijls.v3n1.241

Suriani, N. L. (2016). Identification of the substance bioactive leaf extract Piper Caninum potential as botanical pesticides. Int J Pure App Biosci, 4(4), 26-32.

Suriani, N. L. (2018). Bioactive substance use of leaf extract of piper caninum blume pressing for blas disease and increase production in rice. International Journal of Life Sciences, 2(2), 42-50. https://doi.org/10.29332/ij1s.v2n2.156

Suriani, N. L., Parwanayoni, N. M. S., \& Suartini, N. M. (2015). Meningkatkan produksi bunga potong anthurium sp melalui pemanfaatan pupuk organik. Buletin Udayana Mengabdi, 15(2), 19-23.

Suriani, N. L., Suprapta, D. N., Sudana, I. M., Temaja, I. R. M., \& Indonesia, D. B. (2015). Antifungal activity of Piper caninum against Pyricularia oryzae Cav. The cause of rice blast disease on rice. Methods, 5(8).

Suryani, S. A. M. P., \& Arya, I. W. (2017). Improving the quality of tilapia (oreochromis niloticus) with consumption measures leaf extract neem (azadirachta indica a. juss) as antiparasitic. International Journal of Life Sciences, 1(3), 28-37. https://doi.org/10.21744/ijls.v1i3.62

Suwandi, A. C., Indraswati, N., \& Ismadji, S. (2012). Adsorption of N-methylated diaminotriphenilmethane dye (malachite green) on natural rarasaponin modified kaolin. Desalination and Water Treatment, 41(1-3), 342-355. https://doi.org/10.1080/19443994.2012.664738

Suwandi, S., Ammar, M., \& Irsan, C. (2012). Aplikasi Ekstrak kompos meningkatkan hasil dan menekan penyakit padi sistem ratun di sawah pasang surut Kabupaten Banyuasin. Jurnal Lahan Suboptimal: Journal of Suboptimal Lands, 1(2).

Suriani, N. L. (2019). Piper caninum blume leaf extract and compost to suppress blast disease and increase the production of bali red rice (oryza sativa) in green house. International Research Journal of Engineering, IT \& Scientific Research, 5(4), 46-54. https://doi.org/10.21744/irjeis.v5n4.693 
Yadav, D. K., Kumar, S., Misra, S., Yadav, L., Teli, M., Sharma, P., ... \& Kim, M. H. (2018). Molecular insights into the interaction of rons and thieno [3, 2-c] pyran analogs with SIRT6/COX-2: a molecular dynamics study. Scientific reports, 8(1), 4777. https://doi.org/10.1038/s41598-018-22972-9

Yadav, R. N., Mishra, D., Zaidi, N. W., Singh, U. S., \& Singh, H. B. (2018). Bio-Control efficacy of Trichoderma spp. against the major diseases of rice (Oryzae sativa L.). International Journal of Agriculture, Environment and Biotechnology, 11(3), 543-548.

Yuliani, D., \& Maryana, Y. E. (2014, September). Integrasi teknologi pengendalian penyakit blas pada tanaman padi di lahan sub-optimal. In Di dalam: Prosiding Seminar Nasional Lahan Suboptimal (pp. 26-27).

Yurida, M., Afriani, E., \& Arita, S. (2013). Pengaruh Kandungan CaO dari Jenis Adsorben Semen Terhadap Kemurnian Gliserol. Jurnal Teknik Kimia, 19(2).

Yutida, S. H. Nurdin, M. \& Suskandini, R. D. (2014). Penggunaan Trichoderma sp sebagai Agensia Pengendalian Terhadap Pyricularia oryzae Cav. Penyebab blas pada Padi. J. Agrotek Tropika 2(3): 414-418.

\section{Biography of Author}

Dr. Ni Luh Suriani, SSi., M.Si., graduated her bachelor degree in Udayana University.
She finished her master degree in the Institute of Pertanian Bogor. She completed her
doctoral degree in Udayana University. She is interested in Biology, Environmental,
and Agriculture.
Email: niluhsurianisuriani@yahoo.com

